
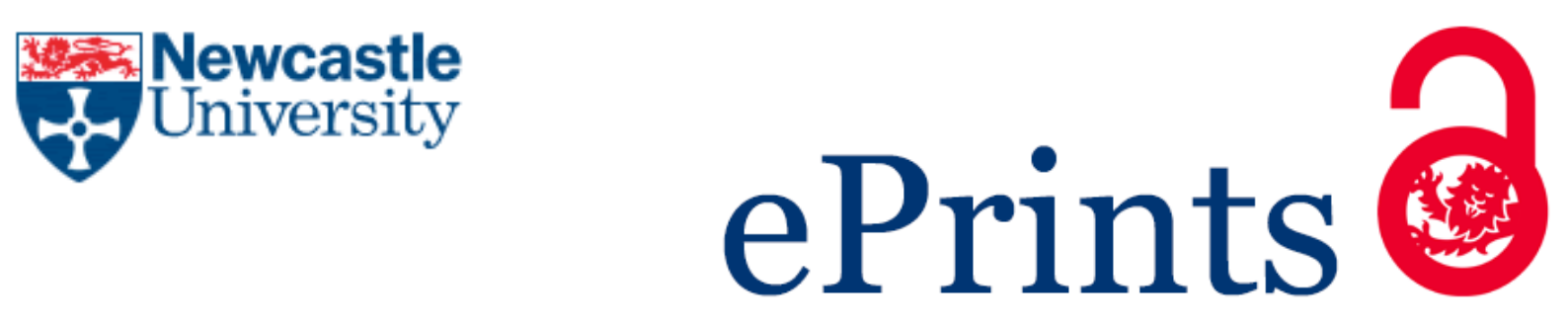

Martin R, Pike A, Tyler P, Gardiner B.

Spatially Rebalancing the UK Economy: Towards a New Policy Model?

Regional Studies 2016, 50(2), 342-357.

\title{
Copyright:
}

This is an Accepted Manuscript of an article published by Taylor \& Francis in Regional Studies on 20/12/2015, available online: http://dx.doi.org/10.1080/00343404.2015.1118450

Date deposited:

$12 / 11 / 2015$

Embargo release date:

20 June 2017

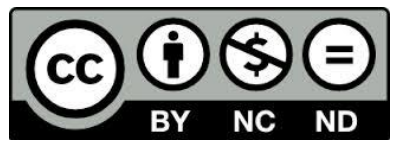

This work is licensed under a

Creative Commons Attribution-NonCommercial-NoDerivatives 4.0 International licence 


\section{Spatially Rebalancing the UK Economy: Towards a New Policy Model?}

Ron Martin*, Andy Pike**, Peter Tyler*** and Ben Gardiner****

*Department of Geography, University of Cambridge

** Centre for Urban and Regional Development Studies (CURDS), Newcastle University

*** Department of Land Economy, University of Cambridge

**** Cambridge Econometrics, Cambridge

Revised Paper for 'Policy Debates', Regional Studies

October 2015 


\section{INTRODUCTION: THE VEXED ISSUE OF SPATIAL ECONOMIC IMBALANCE IN THE UK}

Stimulated by the global financial crisis of 2007-08 and the Great Recession that this triggered, the notion of 'rebalancing the economy' has risen to prominence in UK policy discourse. An important element of this new 'rebalancing' mantra is a concern that the national economy has become too dependent on and dominated by London and the South East, whilst the rest of the country is performing below its potential. ${ }^{1}$ As Prime Minister David Cameron noted upon assuming office in 2010:

Our economy has become more and more unbalanced, with our fortunes hitched to a few industries in one corner of the country, while we let other sectors like manufacturing slide. Today our economy is heavily reliant on just a few industries and a few regions - particularly London and the South East. This really matters. An economy with such a narrow foundation for growth is fundamentally unstable and wasteful - because we are not making use of the talent out there in all parts of our United Kingdom. We are determined that should change (David Cameron, Prime Minister, 2010).

Part of the Government's policy is the aim to promote a 'northern powerhouse' to rival London and the South East in scale and scope:

The cities of the north are individually strong, but collectively not strong enough. The whole is less than the sum of its parts. So the powerhouse of London dominates more and more. And that's not healthy for our economy... We need a Northern Powerhouse too. Not one city, but a collection of northern cities - sufficiently close to each other that combined can take on the world (George Osborne, Chancellor of the Exchequer, 2014).

However, the UK Government is also anxious that the growth of London is not hindered or compromised in any way. As a recent UK Treasury statement put it:

Successful rebalancing will not be achieved by pulling down the capital city, but by building up the Northern Powerhouse and creating strong city regions, led by powerful, democratically elected mayors, that benefit from investment in world-class transport and have the support they need to foster innovation (HM Treasury, 2015, p. 70).

Herein lies a key conundrum: how to achieve a greater degree of 'spatial balance' in the economy whilst also wanting to protect and enhance the gains from spatial agglomeration of economic activity and growth in the already prosperous

\footnotetext{
$\mathbf{1}$ The issue of spatial economic rebalancing is not unique to the UK, of course. It has become a topic of academic and political concern in several other countries - from China to Chile to the European Union - where uneven regional development pose problems for economic, financial and social stability.
} 
London-South East region. Much of the debate surrounding this issue has revolved around a stark question: 'is London good or bad for the rest of the UK'? On the one side are those who point to the benefits of the Greater London economic machine in generating demand for goods and services in the rest of the $\mathrm{UK}$, as a vital source of export earnings, and as a major contributor to the taxes needed to help fund welfare payments and public spending across the nation as a whole (see, for example, City of London Corporation, 2011, 2014). On the other side are those who see London as akin to a 'country apart', even a quasiindependent 'city-state', and a region which has become increasingly detached from the rest of the UK in terms of its level of prosperity, its economic growth, its global orientation, and its cyclical behaviour (Deutsche Bank, 2013). Some go further, and regard it as having become a sort of 'economic black hole', sucking in key human and financial resources from, and to the detriment of, the rest of the UK. Indeed, as Vince Cable, Secretary of State for Business, Innovation and Skills under the Coalition Government of 2010-2015, ventured:

One of the big problems that we have at the moment... is that London is becoming a kind of giant suction machine, draining the life out of the rest of the country (Cable, 2013).

A similar view was subsequently voiced by Scotland's First Minister:

London has a centrifugal pull on talent, investment and business from the rest of Europe and the world. That brings benefits to the broader UK economy. But as we know, that same centrifugal pull is felt by the rest of us across the UK, often to our detriment. The challenge for us all is how to balance this in our best interests (Nicola Sturgeon, 2014).

But this concern over an economy tipped too far towards London is actually nothing new (see Martin, 2015). We have been here before, repeatedly. As early as 1919, the famous geographer (and Unionist MP) Halford Mackinder had argued for a more 'balanced' national socio-economy:

As long as you allow a great metropolis to drain most of the best young brains from the local communities, to cite only one aspect of what goes on, so long must organizations centre unduly in the metropolis and become inevitably an organization of nation-wide classes and interests (Mackinder, 1919, p. 241).

And in equally emphatic terms, the milestone Barlow Commission report in 1940 on the distribution of the nation's industrial population expressed a similar view, again in language highly prescient of that used by Vince Cable nearly seventy-five years later:

The contribution in one area of such a large proportion of the national population as is contained in Greater London, and the 
attraction to the Metropolis of the best industrial, financial, commercial and general ability, represents a serious drain on the rest of the country (Barlow Commission, 1940, para. 171).

What is clear is that the problem and pattern of uneven regional development - of spatial economic imbalance - in the UK economy is a deeply entrenched and persistent feature, going back to the Victorian era if not earlier (Table 1).

Table 1: Spatial Imbalance in the British Economy, 1871-2001: Regional GDP per Capita Relative to the Great Britain Average (GB=100)

\begin{tabular}{|lrrrr|}
\hline GB=100 & $\mathbf{1 8 7 1}$ & $\mathbf{1 9 1 1}$ & $\mathbf{1 9 7 1}$ & $\mathbf{1 9 8 1}$ \\
London & 147.3 & 165.6 & 123.4 & 126.0 \\
South East & 88.5 & 124.6 & 104.6 & 108.4 \\
East Anglia & 97.0 & 76.8 & 92.8 & 94.7 \\
South West & 88.6 & 85.7 & 93.9 & 91.8 \\
East Midlands & 106.2 & 90.6 & 95.7 & 95.6 \\
West Midlands & 84.8 & 78.4 & 101.9 & 95.6 \\
Yorks-Humberside & 91.3 & 76.2 & 92.5 & 90.2 \\
North West & 106.0 & 97.2 & 95.3 & 92.9 \\
North & 94.1 & 89.5 & 86.1 & 92.2 \\
Wales & 87.7 & 90.1 & 87.5 & 82.0 \\
Scotland & 89.9 & 102.1 & 92.2 & 94.8 \\
Coefficient of Variation (\%) & $\mathbf{1 7 . 7}$ & $\mathbf{2 4 . 9}$ & $\mathbf{1 0 . 5}$ & $\mathbf{1 1 . 6}$ \\
\hline
\end{tabular}

Source of Data: Crafts (2005). Northern Ireland is omitted due to lack of consistent comparable historical data. The estimates refer to the old 'Standard Regions', and are derived mainly from individual tax returns, and hence are essentially residence based. 
Figure 1: Cumulative Annual Percentage Point Growth Gaps I Gross Value Added (2011 prices): The South, London and the North, 1971-2013

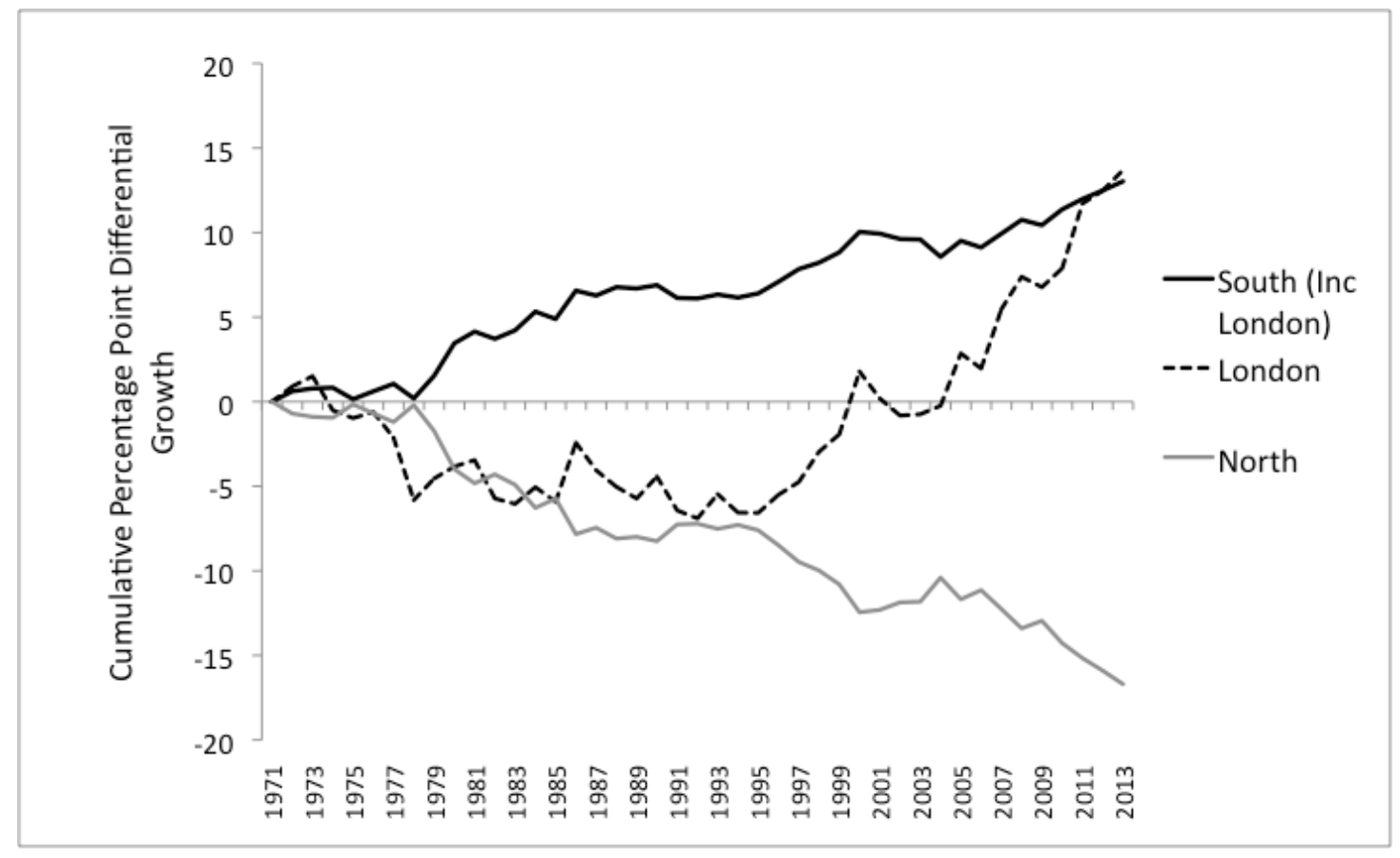

Note: Cumulative growth gap measured as regional rate of growth minus UK rate of growth each year, and summed over time. The methodology is that used by Blanchard and Katz (1992) in their seminal study of regional economic evolutions in the United States. The 'South' is defined as: London, the South East, South West, East of England and East Midlands. The 'North' comprises the West Midlands, Yorkshire-Humberside, North East, North West, Wales, Scotland and Northern Ireland.

Source of Data: Cambridge Econometrics, UK Regional Economic Data Base

While the scale of the problem did seem to lessen somewhat over the course of the post-war period up to the mid-1970s, it has never really disappeared, and has resurfaced with a vengeance over the past twenty years. London and the South of England have grown much faster than the rest of nation (Martin, 2004; Rowthorn, 2010; Figure 1), and have pulled progressively ahead in terms of GDP per capita (Table 2). The UK now has one of the highest levels of spatial economic disparity of any of the major West European countries (Table 3).

The problem of spatial economic imbalance has thus been a long-standing one in the UK and one to which the Government has given varying attention over the years. Numerous different initiatives have been applied for nearly nine decades, and while during the post-war 'long boom' (roughly 1950-1975) regional policy reduced the degree of spatial imbalance compared to what it might otherwise have been, as a whole past policies have failed to have any lasting impact. The next section considers why past policies have proved disappointing. 
Table 2: Spatial Imbalance in the UK Economy, 1988-2013:

Regional GDP per Capita Relative to the UK Average (UK=100)

\begin{tabular}{|lrrrrrr|}
\hline UK=100 & $\mathbf{1 9 8 8}$ & $\mathbf{1 9 9 3}$ & $\mathbf{1 9 9 8}$ & $\mathbf{2 0 0 3}$ & $\mathbf{2 0 0 8}$ & $\mathbf{2 0 1 3}$ \\
London & 152 & 149 & 152 & 162 & 169 & 172 \\
South East & 102 & 102 & 106 & 108 & 109 & 110 \\
East of England & 97 & 95 & 99 & 100 & 97 & 94 \\
South West & 93 & 92 & 89 & 92 & 92 & 91 \\
East Midlands & 97 & 94 & 93 & 90 & 88 & 83 \\
West Midlands & 93 & 92 & 93 & 88 & 85 & 83 \\
Yorks-Humberside & 91 & 90 & 89 & 87 & 84 & 81 \\
North West & 92 & 91 & 89 & 87 & 86 & 85 \\
North East & 85 & 86 & 80 & 78 & 76 & 74 \\
Wales & 85 & 84 & 79 & 76 & 72 & 72 \\
Scotland & 99 & 101 & 96 & 94 & 96 & 94 \\
N Ireland & 75 & 79 & 81 & 79 & 79 & 77 \\
Coefficient of Variation (\%) & $\mathbf{1 8 . 8}$ & $\mathbf{1 7 . 8}$ & $\mathbf{1 9 . 5}$ & $\mathbf{2 2 . 9}$ & $\mathbf{2 5 . 5}$ & $\mathbf{2 6 . 9}$ \\
\hline
\end{tabular}

Source of Data: Office for National Statistics. The currently used Government Office regions in this table differ slightly from the former old Standard Regions shown in Table 1, and also include Northern Ireland. The data are also workplace based, rather than residence based.

Table 3: Spatial Imbalance in Selected EU Countries: Coefficient of Variation in Regional GDP per Capita, (PPS, NUTS2 Regions)

\begin{tabular}{|llll|}
\hline $\begin{array}{l}\text { Coefficient of } \\
\text { Variation (\%) }\end{array}$ & $\mathbf{1 9 8 0}$ & $\mathbf{2 0 0 1}$ & $\mathbf{2 0 1 1}$ \\
United Kingdom & $\mathbf{0 . 3 1}$ & $\mathbf{0 . 3 6}$ & $\mathbf{0 . 4 5}$ \\
Belgium & 0.43 & 0.44 & 0.37 \\
Germany & 0.35 & 0.23 & 0.23 \\
Italy & 0.32 & 0.28 & 0.22 \\
Netherlands & 0.17 & 0.20 & 0.21 \\
France & 0.15 & 0.18 & 0.19 \\
Spain & 0.14 & 0.19 & 0.15 \\
Greece & 0.35 & 0.21 & 0.14 \\
EU-15 & 0.32 & 0.28 & 0.33 \\
\hline
\end{tabular}

Source of Data: Cambridge Econometrics, European Regional Data Base 


\section{THE LIMITED IMPACT OF PAST UK REGIONAL POLICIES}

Since the 1920s, successive UK governments have pursued regional and urban policies of various kinds aimed at reducing spatial disparities in economic prosperity and performance across the country. ${ }^{2}$ The first main political experiment was the Industrial Transference Act (1928), which was designed to diffuse social unrest in the areas of structurally declining coalmining and heavy industry of northern England, central Scotland and South Wales, by encouraging the unemployed in these areas to move to jobs and training schemes in the south and east of England. This 'taking workers to the work' scheme had a limited impact, however, and by 1932 was in decline. Its successor, the Special Areas Act of 1934, took a different approach of providing government built industrial premises and grants in the depressed areas to encourage local investment and jobs there, in effect a 'taking work to the workers' policy. Although this new experiment was a response to the problem in the 'special areas', it was overshadowed by a government concern, echoed by leading economists of the day, to provide a general economy-wide stimulus to ensure sustained recovery from the Great Depression (see Parsons 1986). Indeed, John Maynard Keynes argued that the 'central problem' was one of general prosperity, and the difficulties of the depressed areas were best solved by increased economic activity and demand in the prosperous parts of the country rather than investment directed towards the depressed areas themselves. His General Theory (1936) singularly failed to consider that a national multiplier effect would not necessarily lead to recovery and economic renewal in the depressed regions. Only a year after, however, though mainly in light of the growing pressures on southern industries of the country's rearmament programme, he recognised that the economy had by then reached a stage in which a general stimulus was no longer enough, and that the country was more in need of "a rightly distributed demand than of greater aggregate demand" and that "to remedy the condition of the distressed areas ad hoc measures are necessary" (1937, pp. 13-14).

Modern British regional policy really began in 1945. Infused with ideas and imperatives forged in the Second World War related to the centralizing tendencies and exigencies of a war-time economy, the goals of post-war reconstruction, the notions of a 'balanced distribution of industry' found in the Barlow Commission's Report, and a new commitment to town and country

\footnotetext{
${ }^{2}$ Space does not permit a detailed historical exegesis and evaluation of British regional policy here, and what follows is intended simply to point up the main continuities and shifts in policy that have occurred over the past ninety years. The key message we want to convey is that despite this long development, and the different variants policies have assumed over this time, their overall impact on spatially rebalancing the economy was relatively limited.
} 
planning, the 1945 Distribution of Industry Act set the broad framework and orientation of a regional policy model that was to last more or less intact for the next 35 years. Based on a combination of constraints and controls on manufacturing and then also services-based office growth in London and the South East, combined with a series of capital grants in the designated depressed areas of the country, the aim was to divert economic activity and jobs from the former to the latter. This approach was applied extensively over the period 1960 to 1981 , and it has been estimated that regional policy added an extra 630,000 additional jobs as at 1981 to the economies of the Development Areas (Moore, Rhodes and Tyler, 1986), though a not insignificant number of those jobs were in branch plants of UK companies based elsewhere in the country or of foreign multinationals. However, by the end of the 1970s deindustrialisation had firmly set in, the supply of 'footloose' manufacturing investment was drying up, and the regions of the country defined as depressed and in need of government assistance had steadily grown and spread outwards and southwards from the original areas designated in 1945 to embrace some 42 percent of the nation's working population, itself an indication that regional economic disparities were beginning to widen once again (see Table 1)

Over the ensuing two decades (and especially under the three successive Thatcher governments) this post-war regional policy model was progressively downgraded. The regional policy map was rolled back geographically (to 24 percent of the working population) and made much more spatially fragmented, policy became much more discretionary, and the funding committed to it was reduced significantly. ${ }^{3}$ Another shift in policy came in 1997 with the election of the first of the New Labour governments. A new, 'third-generation' regional policy model was forged on the argument that the best approach to fostering growth in all of the regions - not just the lagging northern regions but also the more prosperous regions of the south and east, including London - was to focus on building and releasing the 'endogenous' potential of all such areas, using new Regional Development Agencies as the key institutions by which to achieve this goal. ${ }^{4}$ Spending was increased, to about $£ 2$ billion a year, and by the time that New Labour was ousted by the Conservative-Liberal Democrats Coalition

\footnotetext{
3 The retrenchment in spending on regional policy actually began in 1976, as part of public spending cuts imposed by the then Labour Government in response to conditions imposed by the IMF in return for its financial support to the UK economy to enable it to avoid a national currency crisis. The cuts were continued under the Thatcher administration that followed in 1979.

4 The term used was 'endogenous', and indeed more than once appeal was made by the Government to its commitment to that branch of economics known as 'endogenous growth theory'. But the policy was as much, if more, about charging the Regional Development Agencies to develop and harness the indigenous resources of the regions, hence the claim that this new, 'third generation' regional policy model was to be 'bottom-up' rather than 'top down' (Balls, Healey and Koester, 2003).
} 
Government in 2010, a whole raft of measures (from promoting clusters to labour force skills development) had been handed down to the RDAs.

Opinions as to the impact of the RDAs differed, but in any case no sooner had the Coalition Government been elected than it set about abolishing them, on the grounds that they had proved ineffective, had actually 'distorted market forces', and in any case bore no relationship to meaningful functional economic areas, though little hard evidence was invoked to support any of these criticisms (Pike et al. 2014). What has followed since between 2010-15 has been an emerging shift to various form of 'economic localism', as evinced in a 'local growth agenda' (BIS, 2010), new Local Enterprise Partnerships (no more functionally meaningful than the RDAs these have replaced), Enterprise Zones, a variety of City Deals, and the beginnings of an experiment in limited city-region based devolution and pan-city-regional co-operation, most notably the 'powerhouse' concept championed by the Chancellor the Exchequer principally in northern England but now emerging in the midlands and south west too. We want to discuss these initiatives, and to argue for being far more radical in approaching the problem of spatial economic balance, below. The reason for making such an argument is that, despite nearly ninety years of regional policy interventions, substantial regional disparities in economic prosperity remain have in fact widened to reach levels not seen since the inter-war years. Past efforts to achieve a more spatially balanced distribution of economic activity and economic growth have failed to have any substantial or lasting impact. Why is this? Three possible explanations might be offered.

First, while the funds committed to regional policy measures over the years have certainly not been trivial, it could be argued that the total spend has simply not been enough to achieve the results desired. At its height of about $£ 2$ billion in 1976, just before the then Labour Government was forced drastically to cut public spending in the wake of the financial turmoil and IMF loan, expenditure on regional aid amounted to no more than about $1.5 \%$ of GDP. Such sums were destined only to have a marginal impact on renewing the economies of Britain's northern regions and cities, and at best slowed down the pace of relative decline of these areas. In the same vein, the level of resources that began to be committed to help with the regeneration of the large old Northern cities from the 1980s onwards tended to be relatively small in relation to the nature of the problem being addressed and, moreover, some of monies went to help regenerate London and in particular the Docklands.

A second argument is that the problem was not so much that the funds spent on regional assistance and aid were not significant but that they were 
dwarfed by other forms of government expenditure - on defence, public procurement, gross fixed capital formation in the public corporations, infrastructure and the like - the geographical distribution of which tended to favour the more economically dynamic south of Britain. In effect, the great bulk of public expenditure acted as a form of what Michael Heseltine (as a member of the Thatcher Government) in the mid-1980s described as 'counter-regional policy', working disproportionately to the benefit of the already prosperous areas in the south, helping to stimulate growth there still further. In 1988/89, for example, spending on regional preferential assistance amounted to a mere $£ 617$ million, while government spending on defence, fixed capital formation, general industry support, labour market programmes, and public procurement totalled more than $£ 24$ billion (see Martin, 1993). The prosperous South East alone attracted half of national defence spending, seven times the spend on regional policy aid in that year. Although the North, Wales and Scotland - the main assisted regions at this time - received more from defence spending than in official regional policy aid, the amount received was still only a third of that going to the South East. During these same years, the state was privatising large sections of certain public industries (such as coal and steel), most of which were concentrated in the depressed regions, deepening the deindustrialization in these areas (see Hudson, 1986). Over the post-war period, then, 'non-regional' government expenditures have been vast compared to the sums devoted to official regional policy. These expenditures have had far-reaching direct and indirect effects on the productive capacity and efficiency of the regions. But these effects have been highly differentiated across the country, and in many respects have operated as counter-regional rebalancing policies, favouring the more prosperous South against the North.

A third reason why regional policies have had such limited purchase on spatially rebalancing the national economy lies in the nature and geographical articulation of the UK's system of national political economy. At stake here is the very diagnosis of the country's problem of spatial economic imbalance. During the inter-war years, and throughout much of the post-war period, up until the beginning of the 1980s, the problem was deemed to be structural in nature, a lack of demand for the products and exports of the depressed areas of northern Britain, encumbered as these regions were with old industries faced by more efficient and cheaper competitors elsewhere (often overseas). In short, much of northern Britain had the wrong industries. From the 1980s onwards, the diagnosis shifted away from structural obsolescence to supply-side type explanations, in which the slow growth of the depressed North was attributed to a lack of enterprise, innovation and skills, and to labour market inflexibilities. No doubt elements of each explanation may have had a disproportionate impact on 
northern cities and regions relative to their southern counterparts, but in each case the reasons for these weaknesses have resided in deeper more fundamental and systemic features of the political and institutional landscape of the country, in the geographical fabric of economic governance.

\section{THE CASE FOR A NEW SPATIAL POLITICAL ECONOMY}

The argument that the concentration of economic activity, growth and prosperity in London and the South East is merely testament to the 'natural workings' of market-driven agglomeration tends to miss an important point. While few would deny the role and benefits of economic agglomeration, this fundamental mechanism does not take place in a political-institutional vacuum. To the contrary, it is shaped by the form, operation and spatial organisation of the nation's core institutions, governance structures, political arrangements and policy-making machinery. And in the UK, these structures have themselves become progressively concentrated in London and its environs. This has been a long and highly path dependent process. As the historical seat of national government, the early location of the nation's key financial institutions (the Treasury, the Bank of England, Stock Exchange, Lloyd's Insurance), and its attraction of corporate headquarters, London has long dominated the nation's key institutions and the outlook of the elites within them. Time was when Britain had a local and regional banking system, a network of local stock exchanges in addition to the London market, distributed across some 22 cities, a system of local government municipal finance in which the majority of funds were raised and spent locally, a press system based in the country's major cities, and so on. One by one, these organizations and structures have become rationalized, centralized and controlled from London. Often with explicit or implicit state involvement.

The self-reinforcing spatial 'agglomeration' and interaction of these institutions, from the political, to the financial, to the corporate, to the media, has cemented over time a highly London-centric view of the 'national' economic interest - precisely what Mackinder (op cit) expressed concern over. The unquestioned conventional wisdom is that what is in London's interest is necessarily in the nation's interest. It is certainly the case that much of national policy - such as fiscal and monetary policy, infrastructural policy, welfare spending, and so on - are determined in London. But the fact is the bulk the UK economy, in terms of production and employment, is located outside London and the surrounding South East. Of course, every nation has a capital city, and in many cases the capital contains key national institutions. But in few other 
advanced countries does the national capital exert such dominance and influence as does London over the rest of the UK.

Spatially rebalancing the UK economy is not just about (yet) another round of spatially-focused policy programmes and initiatives seeking to promote the advantages of agglomeration in cities outside London, better co-coordinating economic and spatial planning between the constituent parts of the UK, boosting innovation in the regions, or improving the infrastructures of city-regions outside the south of England, necessary and important though such interventions might be (see, for example, Bailey, Hildreth, and de Propris, 2015). At this potentially decisive moment, the need is for more fundamental change, about the need to undertake a long-overdue spatial rebalancing of the nation's institutional and governance architectures.

To put the issue simply, the time has come in the UK to spatially decentre the power structures that drive and manage economic growth and development. Unless we have a greater spatial balance in those structures, the national economy itself will remain spatially unbalanced. The solution, we suggest, is a much-needed introduction of a federated or semi-federated model of economic and fiscal governance. Some version of regional or city-regional federalism is increasingly the norm in almost all other western advanced economies. Many European countries moved in this direction from the 1980s onwards (Harvie, 1994). Although the UK has moved down the path of devolved powers for Scotland, Wales and Northern Ireland and London since the late 1990s, it has failed to develop the kind of institutionalised frameworks used in federal systems (e.g. Austria, Germany, Switzerland) or countries with devolved systems of government (e.g. Italy, Spain) to coordinate policy objectives and instruments for territorial balance across the constituent parts of the nation. ${ }^{\mathbf{5}}$ Further, the devolution process involving Scotland, Northern Ireland and Wales has failed to attenuate the highly centralised fiscal and governance structure in England.

However, an historic and potentially formative opportunity is opening up, especially in the wake of the Scottish independence referendum in 2014. Further constitutional change in Scotland, with the promise of more devolution of fiscal and policy powers, has been initiated by the Smith Commission, and new powers have been announced for Wales. Changes discussed for Scotland include enabling the Scottish Parliament to be responsible for raising around $40 \%$ of Scottish taxes and allocating around $60 \%$ of its spending. This devolutionary moment has

\footnotetext{
$\mathbf{5}$ Examples of such frameworks include the Federal-State Joint Task 'Improvement of Regional Economic Structure' (Germany), the standing Spatial Development Coordination Conference (Austria), and the Federal-Canton coordination functions of the State Secretariat for Economic Affairs (Switzerland).
} 
encouraged new thinking in England about moving beyond the ad hoc and piecemeal approach to decentralisation and the increasing plethora of largely uncoordinated local and city-based initiatives introduced in recent years (such as the LEPs, the Local Growth Fund, the new Enterprise Zones, the City Deals, Devolution Deals, etc.) towards a new spatially devolved model of economic development. Already in 2012 Lord Heseltine had argued for the devolution $£ 49$ billion of central Government spending each year. The Chancellor of the Exchequer's idea of stimulating a 'northern powerhouse' based on the 'super metro-region' of Liverpool-Manchester-Leeds-Sheffield has itself stimulated a call for 'metro-devo' not only by Greater Manchester, but also by other cityregional and/or county groupings. Indeed, government received 38 proposals for further decentralisation (including 4 from Scotland and Wales) in its latest round of devolution deal-making (O'Brien and Pike 2015). The Cities and Local Government Devolution Bill provides some indication of the Government's proposed direction of travel providing enabling legislation for the devolution of powers to city-regions with elected metro-mayors. Cities will have increased powers over areas including housing, transport, and strategic planning but it is not yet clear what all this will actually add up to in making an effective contribution to spatial economic re-balancing across England.

Together, current developments suggest that the possibility of constructing a new spatially devolved model of political-economic governance within the UK may be emerging. However, at the present time, while these are steps in the right direction, this movement has the hallmarks of relatively ad hoc and piecemeal reform, in which some constituent nations, regions and cities areas will be granted certain devolved powers while others will not - a highly uneven, unequal and potentially unstable and divisive settlement that may do more to promote further spatial imbalance rather than work towards ameliorating it. Places with weaker economies, tax bases and prospects will be rendered fiscally exposed and vulnerable without appropriate safeguards and equalisation mechanisms. We could all too easily end up with a geographically chaotic and divisive system, an outcome unfortunately all too characteristic of the tradition of 'muddling through' in how policy initiatives and reforms tend to be managed in the UK. Rather, what is called for is a coherent and comprehensive UK-wide strategy and long-term plan for addressing spatial imbalances that recognises the new constitutional realities with respect to the Devolved Administrations, and which offers meaningful and appropriately resourced decentralisation to regions or city-regions in England within an overall federal territorial structure that covers the whole of the UK. 
Our purpose here is not to set out the precise and elaborate details of such a new spatial political economy. Such issues require wider social deliberation perhaps through a national constitutional convention for the UK. Rather, our focus is some of the foundational issues, or building blocks, in relation to such a structure, namely: institutionalising spatial economic balance as a policy objective, decentralizing and devolving governance, decentralizing public administration, fiscal devolution, decentralising the financial system, and establishing a national regionally-organized investment bank.

\section{INSTITUTIONALISING SPATIAL ECONOMIC BALANCE AS A POLICY OBJECTIVE}

For too long the notion of what constitutes 'regional (and indeed 'urban') policy has been restricted to the system of officially-designated and specifically spatially-targeted interventions and expenditures. In reality, almost every government policy and form of government expenditure, although ostensibly 'non-spatial', has impacts and repercussions that vary from region to region. As mentioned above, these 'national' policies can even act as 'counterregional' policies, favouring already prosperous regions and cities over less prosperous ones. Given variations in economic structure and competitiveness between the UK regions, for example, there is no form of monetary policy or fiscal policy or government expenditure that is spatially neutral in its effects. Whether it be reductions in the higher rates of income tax, changes in the Bank Rate (for example in response to inflation), cuts in public expenditure (such as reductions in the central government grant to local authorities), or new spending on infrastructure, the impact on economic growth, jobs, and incomes, can be expected to vary from region to region. The positive or negative multiplier effects of increases or reductions in government spending do not fall equally across space. However, these varying impacts are rarely taken into account in the design or implementation of national policies. Put another way, there is a lack of explicit appraisal of what the regional impacts of major spending (or austerity) programmes and policies might be.

As one example, it is well known that geographically concentrated and imbalanced regional development can impart an inflationary bias to the national economy, and thus limit the scope and impact of macro-economic management. London is arguably the most inflation-prone region in the UK, in terms of office rents, housing costs and wages. The last three house-price bubbles have started there and then diffused outwards across the regions. Monetary measures taken to dampen such 'national' inflation waves, such as raising the interest rate, while 
perhaps justifiable and helpful in terms of controlling inflation in the LondonSouth East region, may in fact be quite damaging to economic activity in the North of the country. This was the concern in 1998 when the then Governor of the Bank of England, Eddie George, provoked complaint when he stated that "job losses in the North were an acceptable price to pay for curbing inflation in the south". He went on to add that while rising unemployment in the north east was undesirable "monetary policy can only target the economy as a whole, not particular regions or sectors, however uncomfortable that reality might be" (BBC News, November 5,1998 ). If there is an argument for a more spatially balanced economy, this must surely be a leading contender.

What has long been missing in national policy making is a 'spatial literacy' that attempts to recognise what the regional impacts of a given national economic policy are likely to be, and whether and to what extent that policy can be designed in a way that minimises any adverse or negative impact on the less prosperous regions. In other words, there is a strong case for institutionalising the goal of spatial economic balance within national policymaking, not as some ad hoc add-on, but as an integral component of such policy making. This in turn implies the coordination, wherever possible, of central government national policies and expenditures with one another and with those other measures explicitly targeted to individual regions and cities as part of the rebalancing effort, and using national policies and public investment programmes to help secure spatial balance across the national economy.

A typical case in point is national physical (and soft) infrastructure, particularly as it relates to connectivity. It is widely recognised that modern and efficient public infrastructure is key to economic growth and competitiveness, regionally and nationally, and there is increasing political debate over the need to improve and extend transport links between the regions and between the cities of the UK. This is well illustrated in relation to access to good quality air connections. And yet, as the recent National Task Force on Connectivity (NTFC, 2015) has shown most clearly increased constraints on runway capacity over the last twenty years has led to domestic services from the UK's regions being displaced from Heathrow to Gatwick and other London airports (There are only 7 UK domestic routes left to and from Heathrow compared to the 17 that operated in the late 1980s). The loss of connectivity to the international hub of Heathrow has impacted negatively on the competiveness of businesses outside the South of the United Kingdom. As Lord Shipley remarks in the Forward to the NTCF Report:

A policy of non-intervention has for twenty years led to the prioritisation of international air access over domestic services at Gatwick and Heathrow. 
This policy can no longer be defended when from the middle of the next decade there could be in excess of 250,000 additional take-off and landing slots to be released as a result of a new runway being opened. As we seek to rebalance the country's economy and generate real and lasting growth, domestic air connectivity to and through London and the South East matters greatly. The rest of the UK should no longer be required to rely so heavily on overseas hubs for global connectivity. The UK needs to be able to meet its own strategic infrastructure needs if it is to be able to compete globally' (Lord Shipley, 2015).

As another example, the proposal to build a new high-speed rail link between London and Birmingham, and eventually to Manchester and Leeds (socalled HighSpeed 2), at a possible cost of £50billion or more, has attracted criticism from not only other cities that the proposed new rail link will by-pass and it's lack of connections to such cities but also from other cities in the North and North East which lack a much needed modern and efficient east-west link. At the same time, the Government has frozen part of its $£ 38.5$ billion five-year upgrade to major rail lines in the Midlands and North of England, which hardly squares with its campaign to rebalance the country and create a "northern powerhouse". 6 The problem is that there appears to be no co-ordinated thinking in Government transport infrastructure planning, and certainly a lack of ensuring that major public investments of this kind link to and are consistent with rebalancing objectives.

There is knowledge, experience and models in other countries that can inform how the UK might think about, adapt and develop a more coordinated approach to delivering its national objectives not just on public investment, but also other major expenditure areas such as education, training, research and development and so on, in order to better achieve the objectives of spatial rebalancing. Recognising the particular variegations and historical geographies of national political economies that would need learning from and adapting for the UK situation, an example of a formal system that goes some way to achieve such coordination is the Joint Task 'Improvement of Regional Economic Structures' in Germany (Gemeinschaftsaufgabe Verbesserung der regionalen Wirtschaftsstruktur). This brings together the Federal Government and regional state (land) governments to set out an annual framework plan, with a calibrated voting system to ensure consensus across the levels of government. A more informal model is the Austrian 'Spatial Planning and Development Conference' (Österreiche Raumordnungskonferenz) that coordinates national strategies and the territorial development interests of different levels on a voluntary basis. More generally, there are lessons from countries like Norway which produces a

\footnotetext{
6 See http://www.theguardian.com/uk-news/2015/jun/25/network-rail-chief-to-step-down-as385bn-upgrades-are-delayed
} 
White Paper for each new government - based on extensive research, evaluation and analysis - on the state of regional disparities and the priorities for regional and local development across the country. While there does appear to be a welcome recognition of the importance of spatial rebalancing as a foundation for national growth and prosperity emerging across major Government departments - most recently by the UK Treasury (2015) - this needs to be explicitly institutionalised and coordinated as a key objective within departmental spending and policy programmes, and those programmes should themselves be consistent with the development needs of the regions.

\section{DECENTRALISING AND DEVOLVING GOVERNANCE IN ENGLAND}

Besides the need to institutionalise spatial economic balance within the policy machinery of national government, there is also scope for further decentralising certain sections and functions of central government and the civil service from Whitehall in London to other parts of the UK. Decentralisation not only reduces costs, it increases Whitehall's spatial awareness, and increases the connection of central government with the regions (Smith, 2010). Echoing calls from just over a decade ago (Massey et al, 2003), a new round of public sector dispersal is warranted, and would reinforce the broader decentralization of governance advocated below. The same principles should govern an assessment of decentralization of public administration within Scotland, Wales and Northern Ireland.

The asymmetrical and uneven nature of governance arrangements in the UK is acute. Enhanced decentralisation of the UK's centralised governance system in England could provide the greater powers, freedoms, flexibilities, resources and fiscal capacity required to enable meaningful decisions to be made and funded at appropriate scales. Some kind of road map for decentralisation in the UK would be beneficial to the spatial rebalancing agenda. The road map could outline the vision, direction and speed of travel and address the limitations of the current ad hoc, piecemeal and uneven deal-based approach. The current approach has created uncertainty, generated short-term demands for governance bodies and partners to articulate their propositions, underpinned perpetual reorganisation and only modestly begun to change the structures and cultures of centralisation ingrained in the UK political economy. Moreover, the democratic and political accountability of emergent governance arrangements remains under-developed and appears to have learned little from the public rejection of the elected regional assemblies with limited powers and resources in 2004 (Rallings and Thrasher 2006). While there is some consensus on the failings of the centralised governance system in England, there is much less agreement and clarity on what should replace it. Any new road map charting a 
course through these thorny issues could build upon the UK House of Commons Political and Constitutional Reform Committee's current enquiry into the future of devolution in the UK in the wake of the Scottish independence referendum result and the revived interest in a federal UK (Blick and Jones, 2010).

A basic question, of course, concerns the most appropriate geographical basis for such devolution or decentralisation. The history of economic governance in England is one of "compulsive re-organisation" (Jones 2010: 374) and "perpetual restructuring" (Mulgan 2010: 1) as repeated institutional experiments have tried to address the "missing middle" (Shaw and Greenhalgh 2010: 457) between central and local government. Building on the regional planning system established in the late 1940s, this process resembles a pendulum oscillating in the post-war period between the regional (early 1960s), local (c. 1979-1994), regional (1997-2010) and local (2010-) scales (Pike, et al, 2015). Ideally, the spatial units should be functional economic regions, but practically would need to be built up from existing administrative areas. The former eight English Regional Development Agencies (RDAs), which were based on Government Office Regions, were abolished by the Coalition Government partly on the very grounds that they did not represent meaningful economic units, were too large and unaccountable (Pike, et al., 2014). The thirty-nine Local Enterprise Partnerships, based on groupings of local authority districts, that have been established in place of the RDAs as the basis for the Government's Local Growth Agenda, are supposed to be more meaningful in economic terms. But many of the LEPs are no more functionally meaningful than the former RDAs, many are somewhat arbitrary alliances, several of them overlap, and many are too small (Pike et al. 2015). An alternative approach is to think in terms of cityregions, or what in most cases would be regional groupings (systems) of interconnected cities and their surrounding hinterlands. The emerging 'metroregion' of Liverpool-Manchester-Leeds-Sheffield may well be one such. But the challenge is to partition the whole of the UK into economically meaningful cityregions and associated hinterland areas. The City Growth Commission (2014) has identified some 15 major cities across the UK that could be the cores or joint cores of surrounding linked regions for governance, fiscal and economic policy purposes. But this proposal would leave much of the East of England and South West regions without such units. What is needed is a thorough-going enquiry into how best to define and delineate a nation-wide system of city-regional and county-regional areas that could function as a devolved governance structure able to build capacity to govern and capable of controlling total local public spending, with legal powers to enact joined-up government, power over local property taxes, and powers to reinvest proceeds and savings locally. Such cityregions and county-regions should be democratically constituted, and able to formulate their particular governance structures, for example elected mayors and assemblies, rather than having the imposed from the national centre. Marrying bottom-up and top-down institutional reforms, such functional 
economic groupings will need to be articulated with the emergent administrative map of local authority collaborations emerging across England (Paine and Smulian 2015).

\section{FISCAL DEVOLUTION}

As the UK has sought to come to terms with the spatial consequences of its industrial decline much has been learned about how to enhance the rate of local economic growth. Local areas start with an inherited pattern of land use and a resource base and institutions that were tailored to another era. The legacy of the past can weigh heavily, and adapting to new futures can be difficult. In the last thirty years, the challenge in many areas has been to bring about economic, physical and economic and social renewal and reorientation against a backdrop where much of their existing stock of floorspace, human and physical capital was configured to produce goods that either no longer exist or are now made elsewhere in the world (Baxter, et al, 2007). In order to achieve such renewal and re-orientation, sustained and substantial effort on several fronts is required, including the promotion of entrepreneurship, innovation, investment, and human capital formation (education and skills) and infrastructure modernisation (Gardiner, et al, 2013).

At the present time local growth initiatives across the United Kingdom are struggling to gain traction given the scale of the task of economic transformation and adaptation. New ways have to be found to increase the level of resources that can be levered into or retained and pooled to help promote the local growth process and thus speed up the pace at which change can occur. Local authorities in particular are very constrained in their ability to obtain the resources they need in a highly centralised public finance system dominated by pooling and transfers to the local level from the national centre and characterised by the historical accretion of complex political and institutional accommodations and fixes such as the Barnett Formula. Most of the resources that they receive are hypothecated and allocated on a population basis. UK government departments in Whitehall and the Devolved Administrations still tend to influence and control key decisions in relation to mainstream budgets in the areas of skills, health, housing, business support, and much more.

While the international evidence on the relationships between decentralisation and regional growth is mixed and shaped by the nature and forms of decentralised governance arrangements (Ezcurra and Rodríguez-Pose 2013, Tomaney, et al, 2011), fiscal capacity and powers are seen as critically important. In the UK the proportion of tax set at the local level in the United 
Kingdom is equivalent to $1.7 \%$ of GDP (Parliament UK, 2014). This compares to $15.9 \%$ in Sweden, $15.3 \%$ in Canada, $10.9 \%$ in Germany, and 5.8\% in France. In addition, the proportion of tax revenues to local government as a proportion of total national tax revenue has actually been falling for forty years, from just over $11 \%$ in 1975 to $4.9 \%$ in 2012 (OECD, 2015). The UK is out of line with most other comparable OECD countries where, if anything, the proportion has either remained broadly the same or increased, sometimes quite dramatically as in the case of Italy and France, through meaningful fiscal decentralisation (see Table 4).

Table 4: Attribution of Tax Revenue to Local and Regional Government as a Percentage of Total Tax Revenue

\begin{tabular}{|l|r|r|c|}
\hline Country & $\mathbf{1 9 7 5}$ & $\mathbf{1 9 9 5}$ & $\mathbf{2 0 1 2}$ \\
\hline United States & 34.2 & 33.1 & 35.8 \\
\hline Spain & 4.3 & 13.3 & 42.1 \\
\hline Denmark & 30.4 & 31.9 & 26.9 \\
\hline France & 7.6 & 11.0 & 13.2 \\
\hline Italy & 0.9 & 5.4 & 16.4 \\
\hline Japan & 25.6 & 25.3 & 24.7 \\
\hline Germany & 31.3 & 29.0 & 39.8 \\
\hline United Kingdom & $\mathbf{1 1 . 1}$ & $\mathbf{3 . 7}$ & $\mathbf{4 . 9}$ \\
\hline
\end{tabular}

Source: OECD (2015) Tax Policy Analysis.

In the face of a severe lack of resources in comparison with other countries and faced with the need to address considerable changes to their physical fabric and labour markets, local authorities across the United Kingdom have been forced to rely on relatively inadequate discretionary resources either from UK government in England, or the Devolved Administrations in Scotland, Wales and Northern Ireland - to deliver their local growth agendas and/or work with central government bodies such as the Homes and Communities Agency. They have often had to apply for packages of support from central government that have usually been made available through specific policy initiatives like City Challenge and the Single Regeneration Budget. In other cases, central government has made funding available through initiatives such as Development Corporations and Enterprise Zones.

More recently, City Deals have reflected the same process except the UK government has increasingly sought to ensure that specific targets are met, which has further added to the difficulties and complexities that local authorities face in securing funds (O'Brien and Pike 2015). While the Devolved Administrations have established strategic economic development frameworks, in England the allocation of resources most recently to Local Enterprise 
Partnerships as part of the Growth Deals reflects much the same process. What now exists is a plethora of piecemeal, largely unconnected forms of centralized support (mostly allocated locally on a competitive basis), that do not add up to a systematic, sufficiently-funded or coherent strategy for spatially rebalancing the economy- a situation recognized by the National Audit Office (2014).

It was in recognition of this overly-centralized and under-resourced state of affairs, that Lord Heseltine (2012) identified some $£ 49$ billion of central government spending on skills, infrastructure, employment, housing, regeneration and business support, that he considered could and should be devolved directly to city-regions. While the Government accepted most of Heseltine's recommendations (HM Treasury, 2013) ${ }^{7}$ and in response set up the Local Growth Fund, the scale of resources committed is only just over £2billion. More important is its pledge to bring the total resources under the strategic control of the Local Enterprise Partnerships to £20billion by 2021 HM Treasury, 2013). This commitment would certainly be a significant move towards fiscal devolution. But it would still fall far short of the scale required. It is not just a case of devolving control over certain areas of central government spending to the city regions, but also one of permitting such areas to retain their local receipts from property taxes, business taxes and local services. Greater Manchester alone estimates its receipts to be around $£ 17 \mathrm{billion}$ per annum. And it is far from clear that the system of LEPs is necessarily the most appropriate spatial governance structure through which to achieve this goal. As stated above, many LEPS are not economically meaningful units, nor are they directly accountable as such to local electorates. Yet, as the Government stresses, the issue of local governance is key to the devolution of fiscal resources.

Thus while there is a welcome emerging recognition of the case for a less centralized and better integrated system of public finances in the UK, this historical opportunity needs to be pursued with greater commitment and coherence of purpose. Accountability, transparency and clarity to better connect where money is raised and spent, where this is decided and how it can be used to stimulate and incentivise sustainable growth and development are critical. Equalisation and safety net principles need to be retained too in the context of further decentralisation and localization of the governance and fiscal system. Such reforms may risk opening up further spatial imbalances and fiscal disparities between more and less prosperous places with stronger or weaker tax bases. The more vulnerable places with greater needs will require support to prevent their exposure and manage their vulnerability within any more decentralized system.

\footnotetext{
7 Specifically, 81 (in full or in part) of Heseltine's 89 recommendations.
} 
Much work has already been done to explore the potential of these kinds of reforms. The Commission on the Future of Local Government (2012), for example, has called for greater devolution of powers and funding over the drivers of productivity, skills, transport and innovation as part of creating greater civic enterprise by local authorities. Working with the principal of fair outcomes across London and the country as well as the desire to render the governance of financial decision-making more accountable to residents and businesses in London, the London Finance Commission (2013) suggested the further devolution of fiscal powers including the increase of revenue streams under local control. These include property taxes and eventually the 'full suite' of council tax, business rates, stamp duty land tax, annual tax on enveloped dwellings and capital gains property disposal tax, and reduced restrictions on borrowing for investment. This same reasoning is no less applicable to other city regions across the country, although the highly uneven scale and strength of their tax bases will need to be recognised.

Concrete innovations for fiscal decentralisation across the UK would be meaningful progression of place-based settlements for local authority groupings that are multi-annual, multi-sectoral and provide the opportunity to integrate, connect and provide more certainty for longer-term utilisation and management of (national and local) public sector revenues and assets (Blond and Morrin, 2014). Work on such place-based arrangements including 'Total Place' and 'Community Budgets' has already explored the possibilities and reforms in this area and the Local Government Association (2015) has called for long-term and place-based finance as the default method of funding with appropriate flexibilities, freedoms and reforms built in (see also House of Commons Communities and Local Government, 2013).

\section{DECENTRALISING THE FINANCIAL SYSTEM}

The overly centralized and concentrated financial system in the UK has long been recognized as a consistent and deeply entrenched cause of spatial imbalance within the UK. To compound the problem, UK banks have long ago shifted their lending activities away from industry, in favour of lending to other financial institutions and offering mortgage finance. Back in 1950, some 65 percent of bank lending was to industry; by 2010 that had fallen to 15 percent. Over the same period, lending to financial companies has increased from 10 percent to 38 percent, while mortgage lending, which was zero in 1950, accounted for 40 per cent of lending in 2010 (Bank of England, 2014). Expressed another way, bank loans accounted for only 18 percent of industry financing in 
the UK in 2010; this compares to a corresponding figure of 45 percent in Germany.

The difficulties faced by small- and medium-sized firms in raising capital have been a topic of recurrent concern in the UK. The Government has made much of the need to stimulate advanced manufacturing, as part of its concern to rebalance the economy. Many specialist advanced manufacturing firms are small or medium sized. Some targeted initiatives have been introduced to support SMEs such as the advanced manufacturing supply chain scheme, but the scale of funds committed ( $£ 213$ million, see Department of Business Innovation and Skills (2013)) are able to make only a modest contribution to the task of rebuilding UK manufacturing. If the UK government is serious about increasing its presence in advanced manufacturing, and increasing the productivity and export performance of manufacturing as a whole (HM Treasury, 2015), the funding of new investment is an issue that urgently needs to be addressed. To this end, there would seem to be a very real opportunity to use the tax system in the UK to align the objective of more spatial rebalancing with that of more sectoral rebalancing. Government could establish new 'Advanced Manufacturing Bonds' with favourable tax treatment to increase the flow of funds into advanced manufacturing firms, some of which funds might be available as a result of recent changes to pensions. Many northern cities still have significant manufacturing potential and increased investment in this sector would assist them with their growth agendas.

Moreover, there is evidence that the geographically skewed nature of the capital markets operates in a spatially biased way, creating funding and financing gaps especially for SMEs and firms in economically weaker and peripheral localities and regions. Globalization, technological innovation, competition and mergers and acquisitions have accentuated such centralization and concentration. The UK's financial system is overwhelming concentrated in and controlled from London, and national monetary policy (such as interest rates) has tended to be biased towards the concerns of the capital's financial nexus (Deutsche Bank, 2013). Experience from Germany suggests that a more regionally decentralized financial system is associated with a greater regional evenness in the allocation of funding to SMEs. The German banking system has a significant regional dimension and has traditionally had a close relationship with industry (Hutton, 1995). Likewise, the spatial organisation of the German venture capital market, involving several major centres, contrasts with the situation in the UK, where the venture capital industry is overwhelmingly concentrated in London and the surrounding South East (these two regions contain some 75 percent of the nation's venture capital firms, and account for 
over 60 percent of venture capital investment) (Martin, et al, 2005). Learning from and adapting the experiences of more decentralised systems such as Germany can provide a stimulus for innovation in the UK context.

The uneven access to finance in the UK has prompted the Scottish Government to propose a Scottish Business Bank (replacing the Scottish Investment Bank within Scottish Enterprise) and there is a similar debate in Wales about replacing Finance Wales with a Development Bank for Wales. These debates, and emerging institutions, provide lessons for regionally focused investment institutions for other parts of the UK that would focus on raising funds for financing long-term productive assets and employment creation, especially in the areas of SMEs and infrastructure (Skidelsky, et al., 2011; Dolphin and Nash, 2012; Merlin-Jones, 2012; and Tott, 2012). ${ }^{8}$ Clearly there are issues to be resolved around what form such institutional arrangements might take, such as the remit of the bank, its capitalisation, how it might raise additional funds, its governance structure and potential hurdles to be overcome in setting it up, in particular gaining approval under the EU's state aid rules. However, workable models exist elsewhere for example the German KfW, Finnvera in Finland and the US Small Business Administration. ${ }^{9}$ But what would be a crucial to any new banks remit would be the funding of SMEs in the regions outside London and the South East, given that these regions are already well served by the existing centralized financial system. Regional lending data shows that SMEs in London have huge net positive deposit balances while in many other regions the reverse is the case. New public investment banking arrangements in England would thus need to have a national and international reach married to an explicit regional structure to its organization in order to be close to the local SMEs seeking funding. Such an institution would provide the sub-national focus that is missing for all parts of the UK, and could help ensure a more spatially balanced allocation of finance to private sector activity (Klagge,

\footnotetext{
8 In 2012, the Coalition Government established a national Green Investment Bank (GIB), with publicly funded capitalisation of £3.8billion, with a remit to invest in UK based green infrastructure in energy efficiency, waste and bioenergy, and offshore wind. The Chancellor of the Exchequer has now announced his intention to privatise the GIB (along with several other public assets), to raise monies to reduce the national deficit, a move that has attrcated considerable criticism, including from with Government itself

(http://www.theguardian.com/environment/2015/jun/25/senior-tories-slam-governmentsgreen-investment-bank-sell-off.

9 The German KfW is a state-owned bank with various functions, but its two main activities are financing housing and environmental projects, and providing funds for SMEs. It covers over 90 percent of its borrowing needs in the capital markets, mainly through bonds that are guaranteed by the national government. This allows KfW to raise funds at advantageous conditions. Its exemption from having to pay corporate taxes due to its legal status as a public agency and unremunerated equity provided by its public shareholders allow KfW to provide loans for purposes prescribed by the KfW at lower rates than commercial banks. KfW is not allowed to compete with commercial banks, but it facilitates their business in areas within its mandate.
} 
and Martin, 2005). And as the German system demonstrates, a more spatially decentralized banking structure need not compromise the credit rating of the institutions concerned (Moody's Investor Services, 2013).

\section{CONCLUSION: TIME FOR BOLD CHANGE}

Whether considered at the regional, local or urban scales, entrenched and persistent spatial disparities in economic and social conditions are a strategically important issue for all the major political parties in the UK. The new UK Government has made much of the need to re-balance the geography of the UK economy (HM Treasury, 2015). The growth gap between the South and the North (and indeed between most of the cities in the South and most of those in the North - see Martin et al, (2014)), is long-standing, cumulative and systemic. The problem goes well beyond the economics of urban agglomeration and is rooted in the spatially biased nature of the national political economy (see also, Martin, 2015). It is time to start thinking about radical changes to that national political economy to ensure that the citizens of all the regions and cities of the United Kingdom can share in the opportunities and benefits of sustainable economic growth and development in the years ahead. Such decentralised systems may be better placed to deal with disruptive change and foster institutional and policy innovation to address economic, social and environmental development needs. We have outlined a number of such radical changes to the UK's spatial political economy that are necessary if any substantial and lasting spatial rebalancing of the UK economy is to be secured. Calls were made over a decade ago for 'decentering the nation' (Massey, et al, 2003), and, to date, only limited and modest progress has been made, especially in England. While recognising the difficulties and costs involved in such radical change, especially in a period of austerity, the current juncture is potentially more propitious politically for reviving that call (UK Commission for Employment and Skills, 2011; IPPR North, 2014). Our argument is that a decentralised framework, involving the meaningful extension of devolution in governance, public finance and the financial system, would not only connect to a growing groundswell of support for more decentralization and provide a boost to the prospects for more sustainable growth and development (City Growth Commission, 2015), but should form a key step towards a spatially federated structure for the UK. Unless such a bold step is undertaken, the likelihood is that the issue of spatial imbalance will continue to challenge governments well into the future. 


\section{ACKNOWLEDGEMENTS}

This paper an abridged and revised version of the pamphlet Spatially Rebalancing the UK Economy: The Need for a New Policy Model commissioned by the Regional Studies Association (2014). We are grateful to the association for being able to draw upon that publication. The views expressed in that Pamphlet, as are the views advanced here are entirely our own and do not necessarily reflect those of the Association.

\section{REFERENCES}

BALLS, E., HEALEY, J. and KOESTER, C. (2003) Growing the Local Economy: The Local Dimension. The Smith Institute.

BANK OF ENGLAND (2014) Understanding the Fair Value of Bank Loans, Financial Stability Paper No. 31, Bank of England.

BARLOW COMMISSION (1940) Royal Commission on the Distribution of the Industrial Population, London, H.M. Stationery Office.

BAILEY, D., HILDRETH, P. and DE PRORIS, L. (2015) Mind the Gap! What Might a Place-based Industrial and Regional Look Like? In Bailey, D., Cowling, K. and Tomlinson, P. (Eds.) New Perspectives on Industrial Policy for a Modern Policy, Oxford University Press: Oxford.

BAXTER, C., Tyler, P., Moore, B. C, Morrison, N, McGaffin, R and Otero-Garcia, M. Enterprising Places; Sustaining Competitive Locations for Technology-Based Activity. CMI. Programme on regional Innovation.

BIS (2010). Local Growth: Realising Every Place's Potential, Cm 7961, 28, London.

BLANCHARD, O. J. and KATZ, L.F. (1992) Regional Evolutions, Brookings Papers on Economic Activity, 1, pp. 1-75.

BLICK, A. and JONES, G. (2010) A Federal Future for the UK: the Options, Federal Trust for Education and Research: London.

BLOND, P. and MORRIN, M. (2014) Devo Max - Devo Manc: Place-Based Public Services, ResPublica: London.

CABLE, V. (2013) "London Draining Life out of Rest of Country", http://www.bbc.co.uk/news/uk-politics-25444981

CAMERON, D. (2010) "Transforming the British Economy: Coalition Strategy for Economic Growth”, Speech, 28 May, Prime Minister's Office, London.

CITY OF LONDON CORPORATION (2011) London's Competitive Place in the UK and Global Economies, Research Report, City of London Corporation.

CITY OF LONDON CORPORATION (2014) London's Finances and Revenues, Research Report, City of London Corporation.

CITY GROWTH COMMISSION (2014) Unleashing Metropolitan Growth, London:

Royal Society for the Arts.

CITY GROWTH COMMISSION (2015) Devo-Met: Charting a Path Ahead, London, 
City Growth Commission.

CRAFTS, N. (2005) Regional GDP in Britain, 1971-1911: Some Estimates, Scottish Journal of Political Economy, 52, pp. 54-64.

COMMISSION ON THE FUTURE OF LOCAL GOVERNMENT (2012) Final Report.

DEPARTMENT OF COMMUNITIES AND LOCAL GOVERNMENT (2015), Cities and Local Government Devolution Bill.

http://services.parliament.uk/bills/2015

16/citiesandlocalgovernmentdevolution.html

DEPARTMENT OF BUSINESS, INNOVATION AND SKILLS (2013), Advanced Manufacturing Supply Chain Fund to Create Thousands of New Jobs, London, BIS

DEUTSCHE BANK (2013) London and the UK Economy: In for a Penny, in for a Pound? Special Report, Deutsche Bank Markets Research.

DOLPHIN, T. AND NASH, D. (2012) Investing for the Future, London: IPPR;

EZCURRA, R. and RODRÍGUEZ-POSE, A. (2013) "Political decentralisation, economic growth and regional disparities in the OECD", Regional Studies, $47,3,388-401$.

GARDINER, B, MARTIN, R. L. SUNLEY, P. and TYLER, P. (2013) Spatially Unbalanced Growth in the British Economy, Journal of Economic Geography, 13, pp. 889-928.

HARVIE, C. (1994) The Rise of Regional Europe, London: Routledge.

HESELTINE, M. (2012) No Stone Unturned: In Pursuit of Growth, London: Department for Business, Innovation and Skills.

HM TREASURY (2013) Investing in Britain's Future, Cmnd 8669.

HM TREASURY (2015). Fixing the Foundations: Creating a More Prosperous Nation, London: HM Treasury.

HOPE, N. and LESLIE, C. (2009) Challenging Perspectives: Increasing Whitehall's Spatial Awareness, New Local Government Network: London.

HOUSE OF LORDS (2015). http://www.out-law.com/en/articles/2015/june/billto-devolve-powers-to-city-regions-laid-before-uk-parliament/

HOSE OF COMMONS COMMUNITIES AND LOCAL GOVERNMENT COMMITTEE (2013) Community Budgets, Third Report of Session 2013-14, HC 163, House of Commons: London Community Budgeting;

HUDSON, R. (1986) Producing an industrial wasteland: capital, labour and the State in the North East, in MARTIN, R.L. and ROWTHORN, R.E. (Eds) The Geography of De-industrialisation, London: Macmillan, pp. 169-213.

HUTTON, W. (1995) The State We're In: Why Britain is in Crisis and How to Overcome It, Vintage: London.

IPPR NORTH (2014) Decentralisation Decade: A Plan for Economic Prosperity, Public Service Transformation and Democratic Renewal in England, IPPR North: Newcastle. 
JONES, A. (2010) "Here we go again: the pathology of compulsive reorganisation", Local Economy, 25, 5-6, 373-378.

KEYNES, J.M. (1936) The General Theory of Employment, Interest and Money, London: Macmillan.

KEYNES, J. M. (1937) How to avoid a Slump - Looking Ahead: 1 The Problem of the Steady Level, The Times, 12 January, pp.13-14.

KLAGGE, B. and MARTIN, R. L. (2005) Decentralized versus centralized financial systems: is there a case for local capital markets? Journal of Economic Geography, 5, 4, pp. 387-421

LOCAL GOVERMENT ASSOCIATION (2015) The LGA's Budget 2015 Submission, LGA: London.

LONDON FINANCE COMMISSION (2013) Raising the Capital. Report of the London Finance Commission; LSE.

MACKINDER, H. (1919) Democratic Ideals and Reality: A Study in the Politics of Reconstruction, London: Constable.

MARTIN, R.L.( 1993) Reviving the economic case for regional policy, Ch.15 in HARRISON. R.T. and HART, M. (Eds) Spatial Policy in a Divided Nation, London: Jessica Kingsley, pp. 270-290.

MARTIN, R.L. (2004) The contemporary debate over the North-South Divide: images and realities of regional inequality in late-Twentieth Century Britain, Ch. 2 in BAKER, A.H.R. and BILLINGE, M. D. (Eds) Geographies of England: The North-South Divide, Imagined and Material, Cambridge: Cambridge University Press, pp. 15-44.

MARTIN, R . L. (2015) Spatially rebalancing the British economy: The challenge for regional theory, Territory, Politics and Government,

MARTIN, R.L., BERNDT, C., KLAGGE, B. and SUNLEY, P (2005) Spatial Proximity Effects and Regional Equity Gaps in the Venture Capital Market: Evidence from Germany and the UK, Environment and Planning, A, 27, 1207-1231; Martin, R L. (2013) Financing Business in Slow Growing Regions: Is there a Case for Local Capital Markets? Discussion Paper, North East LEP Independent Economic Review.

MARTIN, R.L., TYLER, P. and GARDINER, B. (2014) The Evolving Economic Performance of UK Cities, Working Paper 5, Foresight: The Future of Cities, UK Government Office for Science; Cities Outlook 2015, Centre for Cities, London.

MASSEY, D., AMIN, A. and THRIFT, N. (2003) Decentering the Nation: A Radical Approach to Regional Inequality, Catalyst: London.

MERLIN-JONES, D. (2012) Extended Lending: The Case for a State-Backed Investment Bank, London: Civitas;

MOODY'S INVESTOR SERVICES (2013) German development banks: strong Public Sector Support and Legal Framework Underpin Aaa-Aa1 ratings, Special Comment, 19 July, Moody's Investor Services: Frankfurt.

MOORE,B. C, RHODES, J. AND TYLER, P. The Effects of Government Regional Economic Policy. Department of Trade and Industry. HMSO. 
MULGAN, G. (2010) "RDA demise", Regeneration and Renewal, 12 July, Regeneration and Renewal: London.

NATIONAL CONNECTIVITY TASK FORCE (2015) http://www.nationalconnectivitytaskforce.co.uk/

NATIONAL AUDIT OFFICE (2014). Funding and Structures for Local Economic Growth, NAO: London.

NORTHERN ECONOMIC FUTURES COMMISSION and IPPR NORTH (2012) Northern Prosperity is National Prosperity: A Strategy for Revitalising the UK Economy, IPPR North: Newcastle

OECD (2015). Tax Policy Analysis, http://www.oecd.org/ctp/tax-policy/revenuestatistics-levels-of-government.htm

O'BRIEN, P. and PIKE, A. (2015) "City Deals, decentralisation and the governance of local infrastructure funding and financing in the UK", National Institute Economic Review, 233, August.

OSBORNE, G. (2014) Osborne, G. (2014) 'We Need a Northern Powerhouse', Speech delivered in Manchester 23 June, (https://www.gov.uk/government/speeches/chancellor-we-need-anorthern-powerhouse)

PAINE, D. and SMULLIAN, M. (2015) Is this the future shape of local government? Local Government Chronicle, 26 February, LGC: London.

PARSONS, D.W. (1986) The Political Economy of British Regional Policy, London: Croom Helm.

PARLIAMENT (2014) Devolution in England: The Case for Local Government, Communities and Local Government Committee.

http://www.publications.parliament.uk/pa/cm201415/cmselect/cmcomlo c/503/50305.htm\#note31

PIKE, A., COOMBES, M., O'BRIEN, P. and TOMANEY, J. (2014) Austerity States, Institutional Dismantling and the Governance of Sub-National Economic Development: the Demise of the Regional Development Agencies in England, Draft Paper, CURDS: Newcastle Upon Tyne.

PIKE, A., MARLOW, D., McCARTHY, A., O'BRIEN, P. and TOMANEY, J. (2015) "Local institutions and local economic development: the Local Enterprise Partnerships in England, 2010-", Cambridge Journal of Regions, Economy and Society, 8, 184-204.

RALLINGS, C. and THRASHER, M. (2006) “Just another expensive talking shop': public attitudes and the 2004 Regional Assembly Referendum in the North East of England", Regional Studies, 40, 8, 927-936.

ROWTHORN, R.E. (2010) Combined and Uneven Development: Reflections on the Norh-South Divide, Spatial Economic Analysis, 5, pp. 363-388.

SHAW, K. and GREENHALGH, P. (2010) "Revisiting the 'missing middle' in English subnational governance", Local Economy, 25, 5-6, 457-475.

SKIDELSKY, R., MARTIN, F. and WIGSTROM, C.W. (2011) Blueprint for a British Investment Bank, Centre for Global Studies, London; 
SMITH,I.R. (2010) Relocation: Transforming Where and How Government Works, London: HM Treasury

STURGEON, N. (2014) Speech to Scotland's Business Sector, Glasgow. Reported in The Herald (Scotland) http://www.heraldscotland.com/politics/scottishpolitics/sturgeon-london-brings-benefits-to-scotlandseconomy.1417439283.

TOMANEY, J., PIKE, A., RODRÍGUEZ-POSE, A., TORRISI, G. and TSELIOS, V. (2011) Decentralisation Outcomes: A Review of Evidence and Analysis of International Data, Report for Communities and Local Government, CURDS: Newcastle University.

TOTT, N. (2012) The case for a British Investment Bank: A report for Labour's Policy: The Labour Party.

UK COMMISSION FOR EMPLOYMENT and SKILLS (2011) Rebalancing the Economy Sectorally and Spatially: An Evidence Review, UKCES: Wath-uponDearne. 